\title{
EFFECTIVENESS OF PERSUASIVE COMMUNICATION TRAINING FOR TUBERCULOSIS DRUG SUPERVISORS IN MEDAN, NORTH SUMATERA
}

\author{
Tissa Hasibuan, Lita Sri Andayani, Rahayu Lubis \\ Faculty of Public Health, Universitas Sumatera Utara, Medan
}

\begin{abstract}
Background: Adherence to tuberculosis (TB) treatment is crucial to achieving cure while avoiding the emergence of drug resistance. Directly observed treatment (DOT) means that a supervisor watches the patient swallowing the tablets. This ensures that a TB patient takes the right drugs, in the right doses, at the right intervals. DOT is applicable in outpatient settings. The supervisor may be a health worker or a trained and supervised member of the community. The effectiveness of drug supervision may be enhanced by improving the supervisor's knowledge, attitude, and skill in persuasive communication so as to enhance patients adherence to TB treatment. This study aimed to determine the effectiveness of training on persuasive communication among TB drug supervisors in Medan, North Sumatera.

Subjects and Methods: This was a quasi experiment (non-randomized) before and after with no control design conducted at Puskesmas (Community Health Center), Medan, North Sumatera. A sample of 18 drug supervisor was selected for this study. The dependent variable was knowledge and attitude about persuasive communication. The independent variable was training on persuasive communication. The data were collected by questionnaire before and after training. The data before and after training were compared and tested by Wilcoxon test.

Results: Both scores of knowledge and attitude in persuasive communication after training were higher than before training, and they were statistically significant.

Conclusion: Training is effective to improve knowledge and attitude in persuasive communication among TB drug supervisors.
\end{abstract}

Keywords: tuberculosis, persuasive communication, drug supervisors

\section{Correspondence:}

Tissa Hasibuan. Faculty of Public Health, Universitas Sumatera Utara, Medan, North Sumatera. Email: tissahsb123@gmail.com. Mobile: +6285275506251. 